\title{
COMPARATIVE CHARACTERISTICS OF ANTIBACTERIAL ACTIVITY OF PLANTS GROWING IN THE CENTRAL PART OF THE REPUBLIC OF TAJIKISTAN
}

\author{
S. SATOROV ${ }^{1}$, F. MIRZOEVA ${ }^{1}$, SH. SATOROV², M.VAKHIDOVA ${ }^{2}$, V. DUSHENKOV ${ }^{3}$
}

1 Department of Microbiology, Immunology and Virology, Avicenna Tajik State Medical University, Dushanbe, Republic of Tajikistan
2 Department of Plant Biology, School of Environmental and Biological Sciences, Rutgers University, New Brunswick, NJ, USA
3 Department of Natural Sciences, Hostos Community College, City University of New York, Bronx, NY, USA

Objective: To evaluate the spectrum of antibacterial activity of plants growing in the central part of the Republic of Tajikistan.

Methods: The antibacterial properties of 18 plant species from the 14 families were studied. The extract samples on dry filter discs were prepared according to the method developed at Rutgers University. Screens-to-Nature (STN) and disc diffusion (DD) methods were used to assess antimicrobial properties of the extracts. The antimicrobial activity of plant extracts was determined against four types of pathogenic standard museum strains of Staphylococcus aureus, Pseudomonas aeruginosa, Escherichia coli, Klebsiella pneumoniae, as well as by using the same types of microorganisms isolated from inpatients (the hospital strains).

Results: Ethanol extract from leaves of Artemisia absinthium demonstrated a broad-spectrum high degree of antimicrobial activity against both reference and hospital strains of $S$. aureus, $P$. aeruginosa and $E$. coli. The Morus nigra extract also showed broad-spectrum activity, however overall antibacterial activity was lower than in A. absinthium. In general, tested extracts were less effective against $E$. coli. None of the 18 tested extracts showed activity against $K$. pneumoniae.

Conclusions: Artemisia absinthium and Morus nigra have a broad-spectrum antimicrobial effect and differ only in the degree of activity. The extracts of Amaranthus tricolor and Arctium tomentosum, Indigofera tinctoria, Punica granatum were characterized by a somewhat narrower spectrum of action. Mentha arvensis and Allium suworowii had approximately the same degree of inhibitory ability.

Keywords: Plants, growth inhibition, extracts, hospital strains of bacteria, reference strains of bacteria.

For citation: Satorov S, Mirzoeva F, Satorov Sh, Vakhidova M, Dushenkov V. Comparative characteristics of antibacterial activity of plants growing in the central part of the Republic of Tajikistan. Vestnik Avitsenny [Avicenna Bulletin]. 2019;21(4):643-54. Available from: https://doi.org/10.25005/2074-0581-201921-4-643-654.

\section{СРАВНИТЕЯЬНАЯ ХАРАКТЕРИСТИКА АНТИБАКТЕРИАЯЬНОЙ АКТИВНОСТИ НЕКОТОРЫХ РАСТЕНИЙ, ПРОИЗРАСТАЮЩИХ В ЦЕНТРАЯЬНОЙ ЧАСТИ РЕСПУБЯИКИ ТАДЖИКИСТАН}

\author{
С. САТОРОВ ${ }^{1}$, Ф. МИРЗОЕВА ${ }^{1}$ Ш. САТОРОВ ${ }^{2}$ М. М. ВАХИДОВА ${ }^{2}$, В. ДУШЕНКОВ ${ }^{3}$
}

1 Кафедра микробиологии, иммунологии и вирусологии, Таджикский государственный медицинский университет им. Абуали ибни Сино, Душанбе, Республика Таджикистан

2 Кафедра биологии растений, Школа экологических и биологических наук, Ратгерский Университет, Нью Брансвик, США

3 Кафедра естественных наук, Хостоский общественный колледж, Городской Университет Нью-Йорка, Нью-Иорк, США

Цель: Оценить спектр антибактериальной активности некоторых растений, произрастающих в центральной части Республики Таджикистан. Материал и методы: изучены антибактериальные свойства 18 видов растений из 14 семейств. Из растительных препаратов были выделены экстракты, которыми пропитывались стекловатные диски, затем высушенные диски накладывались на поверхность питательной среды, предварительно засеянной культурой микроба. После инкубации по зоне подавления роста микроорганизмов изучалась активность экстрактов растений относительно микроорганизмов. Антимикробная активность растительных экстрактов определялась диско-диффузионным методом с использованием четырёх видов патогенных стандартных музейных штаммов - Staphylococcus aureus, Pseudomonas aeruginosa, Escherichia coli, Klebsiella pneumoniae, - а также с применением этих же видов микроорганизмов, изолированных от стационарных больных. Результаты: экстракт из листьев $A$. absinthium обладает широким противомикробным действием против как музейных, так и изолированных госпитальных штаммов S. aureus, P. aeruginosa u E. coli. Экстракт из Morus nigra также продемонстрировал широкую антимикробную активность, однако несколько меньшую, чем A. absinthium. Протестированные экстракты были менее активны в отношении E. соli. Ни один из используемых 18 экстрактов не проявлял активности по отношению к К. pneumoniae.

Заключение: широким противомикробным действием характеризовались экстракты Artemisia absinthium и Morus nigra и отличились между собой лишь по степени активности. Несколько узким спектром действия характеризовались экстракты Amarantus tricolor, Arctium tomentosum, Indigofera tinctoria, Punica granatum. Экстракты Mentha arvensis и Allium suworowii имели примерно одинаковую степень ингибирующей способности.

Ключевые слова: растения, ингибирование роста, экстракты, госпитальные штаммы бактерий, ресеренсные штаммы бактерий.

Для цитирования: Satorov S, Mirzoeva F, Satorov Sh, Vakhidova M, Dushenkov V. Comparative characteristics of antibacterial activity of plants growing in the central part of the Republic of Tajikistan. Vestnik Avitsenny [Avicenna Bulletin]. 2019;21(4):643-54. Available from: https://doi.org/10.25005/2074-05812019-21-4-643-654. 


\section{INTRODUCTION}

The discovery of the first antibiotic penicillin in 1928 can rightfully be called a revolution in biology, pharmacy and medicine. The synthesis and preparation of this pure antibiotic in the forties of the last century by the "Oxford Group" led by Chain E and Florey HW [1] saved the lives of tens of millions of people who could have die from so-called weak pathogenic bacteria, especially during the World War II [2]. However, the «triumph» did not last long: already during the preclinical trial of penicillin, the problem of antibiotic resistance of microorganisms to this antibiotic arose. A. Fleming in his speech at the Nobel Prize ceremony in medicine warned of the possibility of the formation of resistant microorganisms if antibiotics were used incorrectly, irresponsibly and unnecessarily [3].

The misuse and overuse of antimicrobials are accelerating the development of resistance to antibiotics. The consequences of antimicrobial resistance, besides the failure to treat infections, result in prolonged illness, death, and production losses, including higher costs for treatment and healthcare and drain national and global economies [4,5]. Along with a decrease in the efficacy of antibiotics, another major problem with their use is possible adverse reactions, including their toxicity, especially in children [6]. As it is known, many synthetic antibacterial and antifungal drugs are characterized by ototoxicity, nephrotoxicity, hepatotoxicity, neurotoxicity and the occurrence of allergic reactions. These properties often cause serious complications and disability of patients, even death [7].

Therefore, there is a need to intensify the search for new sources of antibacterial and antifungal compounds, which should have a broad spectrum of action, be characterized by the least toxicity and not have allergic effects. According to most researchers, the most suitable sources are various plants and herbs $[8,9]$.

Given the fact that about 500000 plant species exist on Earth, one can assume that a rich potential supply of medicinal sources, including plants with antibacterial and antifungal properties, is at our disposal [10].

Primitive people began to use plants in the treatment of diseases. Long before our era, written instructions on the types and methods of using herbs in medicine already appeared in ancient Egypt, India, China, and later in Greece and Rome. The number of medicinal plants described in these countries reached 12 thousand species. Of great interest is the so-called Tibetan medicine, which arose about 3000 years $\mathrm{BC}$ based on even more ancient Indian medicine and supplemented by information from Chinese and Mongolian sources [11].

The content of biologically active substances determines the antibacterial and antifungal properties of plants. Among biologically active substances of plant origin with activity against microorganisms, phenolic compounds occupy a special place. Polyphenols, which make up the active substance, are found in many medicinal plants [12].

When searching for plants with antimicrobial activity, it is necessary to bear in mind the fact that the concentration of physiologically active compounds in various plant organs differs, and the chemical composition of each plant organ also varies significantly in different phases of its development $[13,14]$. The Republic of Tajikistan has unique climatic features. The nature of the region is characterized by diversity, sharp contrasts and the presence of magnificent landscapes. The mountainous nature of the terrain and the location of Tajikistan on the border between the temperate and subtropical zones, creates an extreme variety of local climatic conditions $[13,15]$. The exceptional richness of the plant world of the republic, covering both the hot lowlands and the cold peaks of the mountains, depends on this variety of conditions. The flora of Tajikistan is characterized by a tremendous genetic, ecological diversity and exceptional species richness and is represented by 9771 species and 20 types of vegetation [16]. The portion of flowering plants alone includes about 5000 species. From the mentioned number, about 1700 species are included in medicinal plants, which are actively used in phytotherapy [17]. Meanwhile, there is no data about their antibacterial and antifungal effects and their possible application with this purpose.

In this context, it should be noted that in the Republic of Tajikistan the production of antibacterial, antifungal and antiviral drugs has not been established. The need for the population is ensured by the import of antibiotics from countries near and far. As a result, it affects the cost and quality of drugs, because the rules of storage and transportation are not always observed during drug delivery. At the same time, the prevalence of imported innovations significantly limits the development of the infrastructure for the production of new drugs in Tajikistan.

Therefore, one of the urgent tasks of the healthcare authorities and specialists of the Republic of Tajikistan in the field of botany, pharmacy, and medicine is the search for plants with effective antibacterial and antifungal activity, the rational use of medicinal plants and herbal raw materials, as well as the creation and implementation of import-substituting drugs in accordance with principles of evidence-based medicine.

\section{PURPOSE OF RESEARCH}

To evaluate the spectrum of antibacterial activity of selected plants growing in the central part of the Republic of Tajikistan.

\section{MATERIALS AND METHODS}

Plant material. Samples from 18 plant species of the 14 families were collected in an area of the central part of the Republic of Tajikistan in the village of Sufiyon of the Vahdat district and Romit gorge at an altitude of more than 1000 meters above sea level (Table 1).

Preparation of plant extract, filter discs and nutrient agar to determine antibacterial activity. Working concentration and paper discs were prepared according to the method developed at Rutgers University [18]. Briefly, two grams of the plant material was weighed and cut into small pieces with a knife. The sample was placed in a marked by a permanent marker $20 \mathrm{ml}$ scintillation vial. With a clean syringe, four $\mathrm{ml}$ of $95 \%$ ethanol was measured and added to the vial. Grinding and simultaneous extraction of the plant tissue was performed with the specially adapted cordless, variable speed, Dremel rotary tool, Model $8220,12 \mathrm{~V}$ for 10 minutes. The contents of the vial were settled for at least 5 minutes and then filtered $90 \mu$ l of the plant extract were instilled onto each $10 \mathrm{~mm}$ in diameter Whatman1glass microfiber filters, Grade GF/D (Whatman \#1823 \pm 010 , purchased from Millipore, Sigma) carefully monitoring the distribution of the extract so that it was not particularly concentrated in one section of the disc. Discs were dried at room temperature. When air-dried, discs were placed inside the plastic bags pre-labeled with an identification number.

The antimicrobial activity of plant extracts was determined against four types of pathogenic standard reference microorganisms (reference strains): Staphylococcus aureus (ATCC 4929), Pseudomonas aeruginosa (ATCC 4930), Escherichia coli (ATCC 4928), and Klebsiella pneumoniae (ATCC 4927), as well as hospital strains of the same types of bacteria, i.e. strains isolated from inpatient surgical patients. 
Table 1 Plant samples used for antibacterial evaluation

\begin{tabular}{|c|c|c|c|c|c|c|c|}
\hline \multirow{2}{*}{$\begin{array}{l}\text { Sam- } \\
\text { ple } \\
\text { ID }\end{array}$} & \multirow[b]{2}{*}{$\begin{array}{c}\text { Altitude } \\
\text { (m) }\end{array}$} & \multirow[b]{2}{*}{ Longitude } & \multirow[b]{2}{*}{ Latitude } & \multicolumn{2}{|r|}{ Plant } & \multirow[b]{2}{*}{ Family } & \multirow{2}{*}{$\begin{array}{l}\text { Part } \\
\text { used }\end{array}$} \\
\hline & & & & Common name & Scientific name & & \\
\hline \multicolumn{8}{|c|}{ Collected on September 3, 2018 at upper Sufiyon } \\
\hline 01 & 1088 & 38034 ' 7.4" & $69083^{\prime} 4.5^{\prime \prime}$ & Armenian Mallow & Althaea armeniaca Ten. & Malvaceae & Flowers \\
\hline 02 & 1092 & $38034^{\prime} 9^{\prime \prime}$ & $69083^{\prime} 41^{\prime \prime}$ & Dog rose & Rosa canina L. & Rosaceae & Fruit \\
\hline 03 & 1086 & $38034^{\prime} 16.7 "$ & $69083^{\prime} 5^{\prime \prime}$ & Wormwood & Artemisia absinthium $\mathrm{L}$. & Asteraceae & Leaves \\
\hline 04 & 1090 & $38034^{\prime} 8.3^{\prime \prime}$ & $69083^{\prime} 4.8 "$ & Redroot pigweed & Amaranthus retroflexus $\mathrm{L}$. & Amaranthaceae & Stem \\
\hline 05 & 1090 & 38034 ' 7.2" & $69083^{\prime} 5.2^{\prime \prime}$ & Joseph's coat & Amaranthus tricolor $\mathrm{L}$. & Amaranthaceae & Stem \\
\hline 06 & 1089 & 38034 ' 7" & $69083^{\prime} 4^{\prime \prime}$ & Chickweed & Stellaria media (L.) Vill. & Caryophyllaceae & Leaves \\
\hline 07 & 1085 & 38034 ' 6.7" & $69083^{\prime} 3.4^{\prime \prime}$ & Woolly burdock & Arctium tomentosum Mill. & Asteraceae & Seeds \\
\hline 08 & 1085 & $38034^{\prime} 7.3^{\prime \prime}$ & $69083^{\prime} 4.7^{\prime \prime}$ & Henna tree & Lawsonia inermis L. & Lythraceae & Leaves \\
\hline \multicolumn{8}{|c|}{ Collected on September 10, 2018 at lower Sufiyon } \\
\hline 09 & 1091 & $38034^{\prime} 7.3^{\prime \prime}$ & $69083^{\prime} 4.1^{\prime \prime}$ & White mulberry & Morus alba L. & Moraceae & Leaves \\
\hline 10 & 1111 & $38034^{\prime} 17.6 "$ & 690 83' 3.3" & Blackberry & Morus nigra L. & Moraceae & Leaves \\
\hline 11 & 1091 & $38034^{\prime} 7.1^{\prime \prime}$ & $69083^{\prime} 3.3^{\prime \prime}$ & True indigo & Indigofera tinctoria L. & Leguminosae & Leaves \\
\hline 12 & 1092 & 38034 ' 7" & $69083^{\prime} 3.2^{\prime \prime}$ & Corn & Zea mays L. & Poaceae & Stigmas \\
\hline 13 & 1103 & $38034^{\prime} 7.1^{\prime \prime}$ & $69083^{\prime} 3.9 "$ & Mint & Mentha arvensis L. & Lamiaceae & Leaves \\
\hline 14 & 1107 & $38034^{\prime} 17.9^{\prime \prime}$ & 690 83' 2.4" & Buckthorn & Hippophae rhamnoides L. & Elaeagnaceae & Leaves \\
\hline 15 & 1085 & $38034^{\prime} 6.9^{\prime \prime}$ & $69083^{\prime} 3.4^{\prime \prime}$ & Pomegranate & Punica granatum L. & Lythraceae & Leaves \\
\hline 16 & 1090 & 38034 ' 6.9" & $69083^{\prime} 3.2^{\prime \prime}$ & Peppers & Capsicum annuum L. & Solanaceae & Leaves \\
\hline 17 & 1088 & $38034^{\prime} 6.9^{\prime \prime}$ & $69083^{\prime} 3.7^{\prime \prime}$ & Poplar & Populus cataracti Kom. & Salicaceae & Leaves \\
\hline 18 & 1370 & $38044^{\prime} 4.4 "$ & 69020 '0.9" & Allium & Allium suworowii Regel & Alliaceae & Bulb \\
\hline
\end{tabular}

Preparation of inoculum [19]. The bacterial strains were scattered over the surface of the corresponding nutrient media in Petri dishes: S. aureus - on staphyloagar, E. coli - on Endo medium, P. aeruginosa and $K$. pneumoniae - on simple agar. Subsequently, in order to obtain a pure culture, one isolated colony of a certain type was reseeded onto the corresponding slant agar medium. Suspensions (inoculums) were prepared from diurnal cultures of the studied strains using McFarland turbidity $10 \mathrm{IU}$, bringing the final concentration of microorganisms to $2 \times 10^{6} \mathrm{CFU} / \mathrm{ml}$.

Evaluation of the antimicrobial activity of plant extract by Screens-to-Nature Method. We used modified Screens-to-Nature (STN) bioactivity assays developed by Global Institute for BioExploration $[11,20,21]$. Specifically, antibacterial assays were performed in Multiwell Polystyrene Greiner Bio-One 24-well plates, which were provided from the plant laboratory of Rutgers University, USA, i.e. 4 plates for reference and 4 plates for hospital strains of microorganisms ( 1 plate for 1 studied strain).

To prepare the semi-solid nutrient medium, $1.2 \mathrm{~g}$ of LB powder and $0.3 \mathrm{~g}$ of dry agar were added to $30 \mathrm{ml}$ of distilled water. The mixture was thoroughly mixed and autoclaved at $1,200^{\circ} \mathrm{C}$ for 30 minutes. The prepared agar was stored in a water bath (so the agar did not harden) and $300 \mu$ l were poured into each well. The plates were covered with a plate cover and left for 5-10 minutes at room temperature (so that agar hardened). The wells of each plate were numbered by marking the plate cover with the plant ID (Fig. 1).

Then, extracts of a certain plant species were added to the marked wells. The plates were shaken slightly to distribute the extract evenly over the surface of nutrient agar in the wells. After that, $10 \mu \mathrm{l}$ of suspensions of the reference and hospital strains of bacteria used during the procedure were added to each well. To confirm bacterial growth, plant extracts were not added to the wells marked with «-». As a positive control, to the marked «+» wells, were added $10 \mu$ of Twaxipim (Cefepime hydrochloride), an antibiotic that has a wide spectrum of action against gram-positive and gram-negative bacteria. The plates were incubated at $37^{\circ} \mathrm{C}$ for $24-48$ hours. The results of the study were evaluated as follows: the well is covered with a lawn of bacterial growth, no antibacterial activity $(0) ;>50 \%$ of well-covered colonies - low antibacterial activity $(1) ;<50 \%$ - of well-covered colonies - moderate antibacterial activity (2); no colony growth, as in positive control, - high antibacterial activity (3).

Studying the antimicrobial activity of plant extract by disc diffusion method [22]. For this assay, $10 \mu \mathrm{l}$ of suspensions of the studied strains of microorganisms were introduced into the center of the Petri dish with the appropriate nutrient medium and with a sterile spatula distributed over its surface. Discs impregnated with an extract of a certain type of plant were placed on the surface of

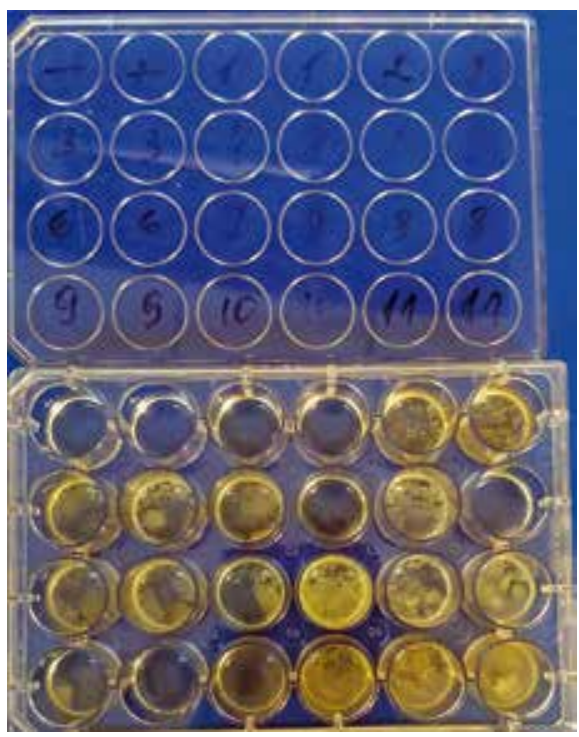

Fig. 1 Determination of antibacterial activity of plant extracts by STN method 
the inoculation at a distance of $2.5 \mathrm{~cm}$ from the center of the dish in a circle. Inoculations were incubated 24-48 hours in an incubator at $36^{\circ} \mathrm{C}$. After incubation in the background of a uniform bacterial lawn around discs with extracts having antibacterial activity, a zone of growth inhibition of colony was observed. The results were taken into account by the presence or absence of growth around a glass wool disc containing an extract of a certain type of plant (Fig. 2).

In the absence of antibacterial activity around the paper disc, a continuous growth of the studied bacterial strain was observed. As a positive control, a paper disc impregnated with Twaxipim (Cefepime hydrochloride) antibiotic solution was used. It was conditionally accepted that the diameter of a growth inhibition of a microorganism over $15 \mathrm{~mm}$ constitute high antibacterial activity (3), 10-15 mm moderate antibacterial activity (2), 6-10 mm - low antibacterial activity (1), no inhibition - no antibacterial activity (0).

\section{RESEARCH RESULTS}

Antibacterial activity of plant extracts against the reference and hospital strains of Staphylococcus aureus. A gram-positive $S$. aureus is a common part of the body microbiota and an opportunistic pathogen. Given the special clinical significance of $S$. aureus [23], and methicillin-resistant strains in particular, initially, the activity of all the extracts was tested against the reference and hospital strains of this bacteria.

As shown in Table 2, from 18 tested plants 14 (A. suworowii, $A$. armeniaca, $A$. tricolor, $A$. tomentosum, $A$. absinthium, $C$. annuum, $H$. rhamnoides, I. tinctoria, L. inermis, $M$. arvensis, M. alba, M. nigra, $P$. granatum, S. media) showed different degrees of antibacterial activity against $S$. aureus strains.

The extracts of $A$. absinthium and $A$. tomentosum exhibited the highest antibacterial activity, both against reference and hospital strains of $S$. aureus. However, for the hospital strain, the antibacterial effect of both extracts was somewhat lower and the growth inhibition zone around the discs impregnated with these extracts was just over $10 \mathrm{~mm}$. The methods used in our assays showed a high

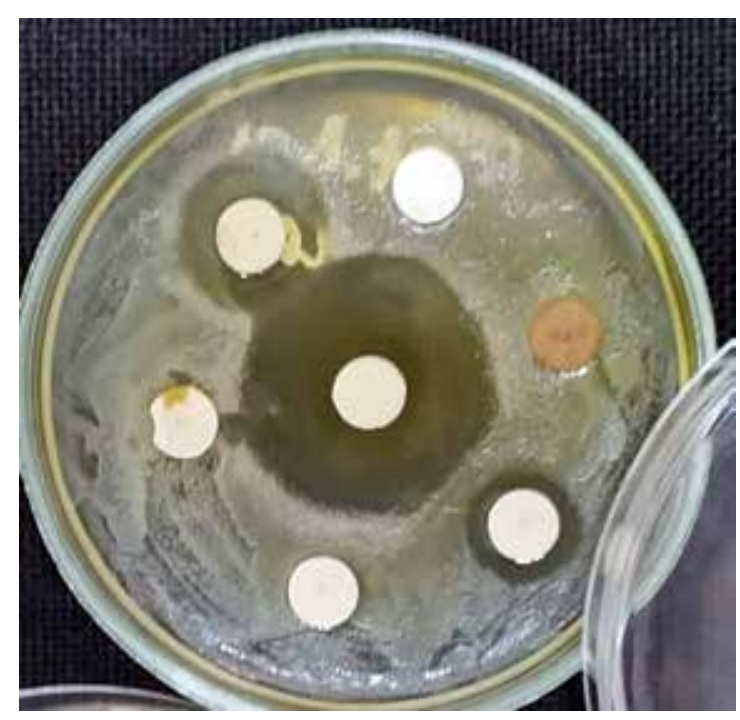

Fig. 2 Determination of antimicrobial activity of plant extracts by disc-diffusion method

consistency of the results. The results obtained by different methods were identical for $83 \%$ tests in the hospital strain and $55 \%$ in the reference strain. When the results were different, with the exception of the reference strain for $A$. suworowii and $M$. arvensis, the higher level of antibacterial activity was observed in the STN assay. For six species (C. annuum, L. inermis, M. alba, M. nigra, P. granatum, $S$. media) a higher level of antibacterial activity against the reverence strain of S. aureus was observed using the STN method compared to the disc diffusion method. Against the hospital strain of S. aureus, a higher level of antibacterial activity was observed for three species (A. suworowii, A. tomentosum, A. absinthium) using the STN method compared to the disc diffusion method. Overall, tested extracts were more active against the reference $S$. aureus strain compared to the hospital strain. In the STN assay six species (C. annuum, L. inermis, M. alba, M. nigra, P. granatum, S. media) and in the disc diffusion

Table 2 Antimicrobial activity of extracts against the reference and hospital strains of Staphylococcus aureus

\begin{tabular}{|c|c|c|c|c|}
\hline \multirow{2}{*}{ Species } & \multicolumn{2}{|c|}{ Reference strain } & \multicolumn{2}{|c|}{ Hospital strain } \\
\hline & STN & Disc diffusion & STN & Disc diffusion \\
\hline Allium suworowii & 1 & 2 & 2 & 1 \\
\hline Althaea armeniaca & 1 & 1 & 1 & 1 \\
\hline Amaranthus retroflexus & 0 & 0 & 0 & 0 \\
\hline Amaranthus tricolor & 1 & 1 & 1 & 1 \\
\hline Arctium tomentosum & 3 & 3 & 3 & 2 \\
\hline Artemisia absinthium & 3 & 3 & 3 & 2 \\
\hline Capsicum annuum & 1 & 0 & 0 & 0 \\
\hline Hippophae rhamnoides & 1 & 1 & 1 & 1 \\
\hline Indigofera tinctoria & 1 & 1 & 1 & 1 \\
\hline Lawsonia inermis & 1 & 0 & 0 & 0 \\
\hline Mentha arvensis & 1 & 2 & 1 & 1 \\
\hline Morus alba & 1 & 0 & 0 & 0 \\
\hline Morus nigra & 2 & 1 & 1 & 1 \\
\hline Populus cataracti & 0 & 0 & 0 & 0 \\
\hline Punica granatum & 1 & 0 & 0 & 0 \\
\hline Rosa canina & 0 & 0 & 0 & 0 \\
\hline Stellaria media & 1 & 0 & 0 & 0 \\
\hline Zea mays & 0 & 0 & 0 & 0 \\
\hline
\end{tabular}


Table 3 Antibacterial activity of extracts against the reference and hospital strains of Pseudomonas aeruginosa

\begin{tabular}{|c|c|c|c|c|}
\hline \multirow{2}{*}{ Species } & \multicolumn{2}{|c|}{ Reference strain } & \multicolumn{2}{|c|}{ Hospital strain } \\
\hline & STN & Discdiffusion & STN & Discdiffusion \\
\hline Allium suworowii & 1 & 1 & 0 & 0 \\
\hline Althaea armeniaca & 1 & 1 & 1 & 1 \\
\hline Amaranthus retroflexus & 0 & 0 & 0 & 0 \\
\hline Amaranthus tricolor & 1 & 1 & 1 & 1 \\
\hline Arctium tomentosum & 3 & 3 & 3 & 2 \\
\hline Artemisia absinthium & 3 & 3 & 3 & 2 \\
\hline Capsicum annuum & 1 & 0 & 0 & 0 \\
\hline Hippophae rhamnoides & 1 & 1 & 1 & 1 \\
\hline Indigofera tinctoria & 1 & 1 & 1 & 1 \\
\hline Lawsonia inermis & 1 & 0 & 0 & 0 \\
\hline Mentha arvensis & 1 & 2 & 1 & 2 \\
\hline Morus alba & 1 & 0 & 0 & 0 \\
\hline Morus nigra & 2 & 1 & 1 & 1 \\
\hline Populus cataracti & 0 & 0 & 0 & 0 \\
\hline Punica granatum & 1 & 0 & 0 & 0 \\
\hline Rosa canina & 0 & 0 & 0 & 0 \\
\hline Stellaria media & 1 & 0 & 0 & 0 \\
\hline Zea mays & 0 & 0 & 0 & 0 \\
\hline
\end{tabular}

test, four species (A. suworowii, A. tomentosum, A. absinthium, $M$. arvensis) exhibited a high level of antimicrobial activity against the reference strain compared to the hospital strain. It is noticeable that plants of the same family and even genus were quite different in antimicrobial properties. For example, extract from $A$. tricolor exhibited at least some antibacterial activity in all tests and $A$. retroflexus did not inhibit bacterial growth. Of the 18 tested extracts, extracts from four plants ( $P$. cataracti, $R$. canina, A. retroflexus, and Z. mays) did not show any antibacterial activity against the reference or hospital staphylococcus strains. In addition, extracts from five species (C. annuum, L. inermis, $M$. alba, P. granatum, S. media) did not suppress the growth of the $S$. aureus hospital strain.

Antibacterial activity of plant extracts relative to the reference and hospital strains of Pseudomonas aeruginosa. A gram-negative $P$. aeruginosa, found in soil, water, is associated with the infection of plants and animals. It is an opportunistic human pathogen linked to a wide range of infections. Human colonization usually begins within the gastrointestinal tract, and subsequently spreads to skin, ear, eye, urinary tract, heart, airway and lung tissues. Nosocomial infections associated with $P$. aeruginosa include gastrointestinal infection, urinary tract infections and bloodstream infection and are difficult to treat due to P. aeruginosa initiate resistance to many antibiotics and its ability to acquire further resistance mechanisms to multiple class of antibiotics [24]. The results for assays with $P$. aeruginosa were similar to the plant extracts antibacterial properties demonstrated with $S$. aureus strains. As exhibited in (Table 3 ), out of 18 tested plant extracts, 14 (A. suworowii, A. armeniaca, A. tricolor, A. tomentosum, A. absinthium, $C$. annuum, H. rhamnoides, I. tinctoria, L. inermis, $M$. arvensis, $M$. alba, M. nigra, P. granatum, S. media) showed different degrees of antibacterial activity against $P$. aeruginosa strains.

The extracts of $A$. absinthium and $A$. tomentosum exhibited the highest antibacterial activity, both against reference and hospital strains of $P$. aeruginosa. However, for the hospital strain, the antimicrobial effect of both extracts was somewhat lower and the growth inhibition zone around the discs impregnated with these extracts was just over $10 \mathrm{~mm}$. The methods used in our assays showed a high consistency of the results. The results obtained by different methods were identical for $83 \%$ tests in the hospital strain and $61 \%$ in the reference strain. When the results were different, with the exception of M. arvensis, the higher level of antibacterial activity was observed in the STN assay. For seven species (A. suworowii, C. annuum, L. inermis, M. alba, M. nigra, P. granatum, S. media), a higher level of antibacterial activity against the reference strain of $P$. aeruginosa was observed using the STN method compared to the disc diffusion method. Against the hospital strain of $P$. aeruginosa, a higher level of antibacterial activity was observed for two species ( $A$. tomentosum, A. absinthium) using the STN method compared to the disc diffusion method. Overall, tested extracts were more active against the reference $P$. aeruginosa strain compared to the hospital strain. In the STN assay seven species (A. suworowii, $C$. annuum, L. inermis, M. alba, M. nigra, P. granatum, S. media) and in the disc diffusion assay, three species (A. suworowii, A. tomentosum, A. absinthium) exhibited a high level of antimicrobial activity against the reference strain compared to the hospital strain. It is noticeable that plants of the same family and even same genus were quite different in antimicrobial properties. For example, extract from $A$. tricolor exhibited at least some antibacterial activity in all tests and $A$. retroflexus did not inhibit $P$. aeruginosa growth. The biggest difference between affecting the growth of $P$. aeruginosa compared to $S$. aureus was observed with activity of $A$. suworowii. This species demonstrated high antibacterial properties against both $S$. aureus strains and was not active against the hospital strain of $P$. aeruginosa. Of the 18 tested extracts, extracts of four plants (P. cataracti, $R$. canina, A. retroflexus, and $Z$. mays) did not show any antibacterial activity against the reference or hospital $P$. aeruginosa strains. In addition, extracts from six species (A. suworowii, C. annuum, L. inermis, M. alba, P. granatum, S. media) did not suppress the growth of $P$. aeruginosa hospital strain.

Antibacterial activity of plant extracts against the reference and hospital strains of Escherichia coli. Most strains of a gram-negative bacterium E. coli are harmless and are part of the normal microflora of the lower intestine. However, some serotypes of $E$. coli can cause serious infections of the gastrointestinal tract and purulent in- 
flammatory processes in various organs. The antibiotic-resistant hospital serotypes of $E$. coli, which cause severe clinical forms of nosocomial infectious pathologies, are of particular interest. Overall the activity of tested extracts against $E$. coli was much lower compared to activity against $S$. aureus and $P$. aeruginosa. Only seven (A. armeniaca, A. retroflexus, A. absinthium, $H$. rhamnoides, M. nigra, S. media, Z. mays) out of 18 extracts showed at least some antimicrobial activity (Table 4). Just the extract of $A$. absinthium exhibited the high antibacterial activity against both reference and hospital strains of E. coli. The methods used to evaluate the antimicrobial potential of plant extracts against $E$. coli showed high consistency of the results.

For the hospital strain $-89 \%$ and for the reference strain $-78 \%$ of the results obtained by different methods were identical. The extract from $A$. retroflexus was moderately active against the reference strain of $E$. coli in both STN and disc diffusion assays. However, only low antibacterial activity was found for this extract against the hospital strain. The extracts of three species (A. armeniaca, $H$. rhamnoides, and $M$. nigra) were found to be moderately active against the reference strain of $E$. coli in the STN assay. In the remaining assays, these species had low activity or, in the case of $H$. rhamnoides, did not affect the hospital strain of E. coli. It is notable that the $Z$. mays extracts showed some low activity against the reference but was ineffective against the hospital $E$. coli strain. It is also noteworthy that the majority of tested extracts ( $A$. suworowii, A. tricolor, A. tomentosum, $C$. annuum, I. tinctorial, $L$. inermis, $M$. arvensis, $M$. alba, $P$. cataracti, $P$. granatum, $R$. canina) did not show any activity against E. coli strains.

Antibacterial activity of plant extracts against the reference and hospital strains of Klebsiella pneumoniae. A gram-negative $K$. pneumoniae is a part of the normal flora of the mouth, skin, and intestines. It is one of the most common nosocomial opportunistic pathogens. The emergence and spread of $K$. pneumoniae antibiotic resistance is well documented [25]. In our assays, none of the tested extracts had an inhibitory effect on strains of these bacteria.

Comparative evaluation of the antimicrobial activity of the plant extracts against bacteria of various groups. The performed STN and disc diffusion antimicrobial assays showed the variability of plant extract activity against different bacteria. Since no extracts demonstrated antimicrobial activity against $K$. pneumoniae, we concentrated on comparative analysis of antimicrobial activity against reference and hospital strains of $S$. aureus, P. aeruginosa and E. coli. The methods used in our assays showed a high consistency of the results. For the three aforementioned bacteria, the results obtained by different methods were identical in $85 \%$ for the hospital strain and $65 \%$ for the reference strain. Table 5 summarized antimicrobial activity identified for tested extracts.

In general, tested extracts were more active against the reference strains of particular bacteria. The extracts were less effective against $E$. coli compared to $S$. aureus and $P$. aeruginosa. The extract from $A$. absinthium leaves demonstrated a broad-spectrum high degree of antimicrobial activity against both reference and hospital strains of S. aureus, $P$. aeruginosa and $E$. coli. The M. nigra leaves extract also showed broad-spectrum activity however, the overall antibacterial activity of this species was lower than of $A$. absinthium. Extracts from $A$. armeniaca and $H$. rhamnoides moderate antibacterial properties against all three types of bacteria. $A$. tomentosum and $M$. arvensis extracts suppressed the growth of $S$. aureus and $P$. aeruginosa while being absolutely ineffective against $E$. coli. Ten species (A. suworowii, A. retroflexus, A. tricolor, C. annuum, I. tinctorial, L. inermis, M. alba, P. granatum, S. media, Z. mays) showed very low antibacterial activity against at least some of the bacteria strains. No antimicrobial activity was observed for $P$. cataracti and $R$. canina extracts.

\section{Discussion}

The increasing multi resistance of human and animal infections to antibacterial drugs is one of the key factors in the search for new antibiotic compounds. In the etiological structure of human infectious pathology, a special place is occupied by antibiotic-resistant clinically significant bacteria, which can be called the leading hospital microorganisms: Staphylococci, P. aeruginosa, and pathogenic

Table 4 Antibacterial activity of extracts against the reference and hospital strains of Escherichia coli

\begin{tabular}{|c|c|c|c|c|}
\hline \multirow{2}{*}{ Species } & \multicolumn{2}{|c|}{ Reference strain } & \multicolumn{2}{|c|}{ Hospital strain } \\
\hline & STN & Disc diffusion & STN & Disc diffusion \\
\hline Allium suworowii & 0 & 0 & 0 & 0 \\
\hline Althaea armeniaca & 2 & 1 & 1 & 1 \\
\hline Amaranthus retroflexus & 2 & 2 & 1 & 1 \\
\hline Amaranthus tricolor & 0 & 0 & 0 & 0 \\
\hline Arctium tomentosum & 0 & 0 & 0 & 0 \\
\hline Artemisia absinthium & 3 & 3 & 3 & 3 \\
\hline Capsicum annuum & 0 & 0 & 0 & 0 \\
\hline Hippophae rhamnoides & 2 & 1 & 1 & 0 \\
\hline Indigofera tinctoria & 0 & 0 & 0 & 0 \\
\hline Lawsonia inermis & 0 & 0 & 0 & 0 \\
\hline Mentha arvensis & 0 & 0 & 0 & 0 \\
\hline Morus nigra & 2 & 1 & 1 & 1 \\
\hline Populus cataracti & 0 & 0 & 0 & 0 \\
\hline Punica granatum & 0 & 0 & 0 & 0 \\
\hline Rosa canina & 0 & 0 & 0 & 0 \\
\hline Stellaria media & 1 & 0 & 0 & 0 \\
\hline Zea mays & 1 & 1 & 1 & 0 \\
\hline
\end{tabular}


Table 5 Comparative analysis of the antibacterial activity of plant extracts against the reference and hospital strains of bacteria. Numbers represent the summary of activity identified by both STN and disc diffusion methods

\begin{tabular}{|c|c|c|c|c|c|c|c|c|}
\hline \multirow{2}{*}{ Species } & \multicolumn{2}{|c|}{ S. aureus } & \multicolumn{2}{|c|}{ P. aureginosa } & \multicolumn{2}{|c|}{ E. coli } & \multicolumn{2}{|c|}{ Cumulative } \\
\hline & Reference & Hospital & Reference & Hospital & Reference & Hospital & Total & Average \\
\hline Artemisia absinthium & 6 & 5 & 6 & 5 & 6 & 6 & 34 & 2.83 \\
\hline Arctium tomentosum & 6 & 5 & 6 & 5 & 0 & 0 & 22 & 1.83 \\
\hline Morus nigra & 3 & 2 & 3 & 2 & 3 & 2 & 15 & 1.25 \\
\hline Althaea armeniaca & 2 & 2 & 2 & 2 & 3 & 2 & 13 & 1.08 \\
\hline Hippophae rhamnoides & 2 & 2 & 2 & 2 & 3 & 1 & 12 & 1.00 \\
\hline Mentha arvensis & 3 & 2 & 3 & 3 & 0 & 0 & 11 & 0.92 \\
\hline Allium suworowii & 3 & 3 & 2 & 0 & 0 & 0 & 8 & 0.67 \\
\hline Amaranthus tricolor & 2 & 2 & 2 & 2 & 0 & 0 & 8 & 0.67 \\
\hline Indigofera tinctoria & 2 & 2 & 2 & 2 & 0 & 0 & 8 & 0.67 \\
\hline Amaranthus retroflexus & 0 & 0 & 0 & 0 & 4 & 2 & 6 & 0.50 \\
\hline Stellaria media & 1 & 0 & 1 & 0 & 1 & 0 & 3 & 0.25 \\
\hline Zea mays & 0 & 0 & 0 & 0 & 2 & 1 & 3 & 0.25 \\
\hline Capsicum annuum & 1 & 0 & 1 & 0 & 0 & 0 & 2 & 0.17 \\
\hline Lawsonia inermis & 1 & 0 & 1 & 0 & 0 & 0 & 2 & 0.17 \\
\hline Morus alba & 1 & 0 & 1 & 0 & 0 & 0 & 2 & 0.17 \\
\hline Punica granatum & 1 & 0 & 1 & 0 & 0 & 0 & 2 & 0.17 \\
\hline Populus cataracti & 0 & 0 & 0 & 0 & 0 & 0 & 0 & 0.00 \\
\hline Rosa canina & 0 & 0 & 0 & 0 & 0 & 0 & 0 & 0.00 \\
\hline
\end{tabular}

0 - no antibacterial activity, 6 - maximum of antibacterial activity with the highest 3 points recorded for each of two methods

strains of E. coli and K. pneumoniae. Our goal was to study the antimicrobial activity of extracts obtained from 18 plant species growing in the central region of the Republic of Tajikistan against these bacteria.

One of the striking differences revealed during the resulting analysis and comparison of our findings with the data of researchers from other countries, is the lack of antimicrobial activity of all tested extracts against the reference and hospital strains of $K$. pneumoniae. Multiple researchers from different countries $[26,27]$ reported a high antimicrobial activity against $K$. pneumoniae of extracts from many plants also used in this work.

In the available literature, there are numerous reports of the pronounced antibacterial activity of extracts obtained from various parts and organs of $A$. absinthium against $S$. aureus, P. aeruginosa, $E$. coli, K. pneumoniae. Interestingly, the opinions of researchers on this issue differ. In the work of Moslemi et al. [28], it has been experimentally shown that this species of Artemisia is characterized by high anti staphylococcal activity. Ahamad et al. [29] also reported high inhibitory effect for the extract from this plant species against $S$. aureus, $P$. aeruginosa, as well as $K$. pneumoniae and not having ability to inhibit the growth of $E$. coli. These data do not always coincide with the results of our studies. The extract we obtained did not exhibit antimicrobial activity against $K$. pneumoniae and simultaneously effectively suppressed the growth of the reference and hospital strains of $E$. coli as well as $S$. aureus, $P$. aeruginosa.

In many countries, the fruits of $M$. nigra, along with being a food source, are widely used to lower blood pressure and as antihyperglycemic, diuretic, antioxidant, antihelminthic, antiparasitic and antibacterial treatments [30,31]. However, information related to the antimicrobial activity of various organs and parts of $M$. nigra varies significantly. According to Aulifa et al. [31], extracts obtained from the stem bark, fruits, and fresh black mulberry juice had an inhibitory effect on S. epidermidis, but leaf extract had only a moderate antimicrobial effect on strains of these bacteria. A substantial degree of bactericidal action of the extract from the leaves of this type of mulberry against the reference strains of $S$. aureus, $E$. coli and $K$. pneumoniae were reported by Khalid et al. [32]. In our case, the extract from the leaves of $M$. nigra inhibited the growth of the reference and hospital strains of $S$. aureus, $P$. aeruginosa, and $E$. coli and did not have effect $K$. pneumoniae strains.

A. armeniaca reportedly is being used in folk medicine as treatment for pneumonia, kidney ailments, and anti-hemorrhagic agent [33]. Similar to A. absinthium and M. nigra, extracts from A. armeniaca flowers had broad-spectrum antibacterial effect. However, $A$. armeniaca effect on the growth of reference and hospital strains of $S$. aureus, $P$. aeruginosa, and $E$. coli was very low. It was demonstrated that methanol extracts of aerial parts of other Althaea species, A. officinalis $L$. and $A$. cannabina $L$. exhibited significant antibacterial activity against a range of food borne bacteria [34].

Health benefits of sea buckthorn ( $H$. rhamnoides) fruits and seeds are well known [35-37]. Much less is known about the potential biological activity of leaves [38]. Rich in bioactive phytochemicals [39] the extract from $H$. rhamnoides leaves had a broad-spectrum moderate antibacterial activity and inhibited the growth of all tested strains of $S$. aureus $P$. aeruginosa and $E$. coli. This concurs with the results of other authors. Marked antibacterial activity of aqueous and hydroalcoholic extracts of Sea buckthorn leaves was shown against E. coli, Enterococcus durans, Bacillus cereus, P. aeruginosa, S. aureus and Enterococcus faecalis [38-40].

According to the scientific literature, in folk medicine of different countries, various species of the Arctium genus have been widely used since the ancient times [41] as food [42] and medicine [43]. The chemical composition and healing properties of Arctium lappa L. are well researched $[44,45]$. Infusions and extracts from various parts and organs of this species of burdock have bactericidal activity against many human infectious agents and are used to treat pathologies of a bacterial, viral and parasitic nature $[46,47]$. Experimental studies have established that extracts of this plant species have 
an anti-tuberculosis effect [48]. However, in the scientific literature we found insufficient information about the antimicrobial activity of A. tomentosum, the most widespread species of burdock in Central Asia. In the Republic of Belarus, fresh leaves of $A$. tomentosum are commonly used as anti-inflammatory agent to alleviate localized pain [49]. Our studies showed that the extract from the leaves of this species of burdock shows antibacterial activity against strains of $S$. aureus and $P$. aeruginosa but does not inhibit the growth of $E$. coli and $K$. pneumoniae strains. It is necessary to note that scientific information on the antimicrobial properties of representatives of the Arctium genus, in particular the activity of the A. lappa, is ambiguous. Some authors [50] report that extracts obtained from the roots, trunk, or leaves of $A$. lappa are characterized by high bactericidal activity against $E$. coli. Other researchers [51] reported the absence of antimicrobial activity of this species against $E$. coli, which coincides with the results of our observation, despite the fact that we used an extract from another species of burdock (A. tomentosum).

Peppermint ( $M$. arvensis) one of the world oldest and popular herbs used in cosmetics, food and medicine $[52,53]$. At the present stage, its extracts and oil are used in various branches of medicine in dentistry, dermatology, therapy, treatment of infectious diseases and as an anti-inflammatory agent [53]. In our studies, the extract from the leaves of this plant showed low inhibitory activity against reference and hospital strains of $S$. aureus and $P$. aeruginosa, did not affect strains of $E$. coli and Klebsiella, which does not coincide with the results obtained by other researchers [54-56], who reported a high inhibitory activity against the above mentioned bacteria.

We found that the extract from $A$. tricolor has a pronounced antibacterial effect against the reference and hospital strains of staphylococcus. Here, our results do not coincide with the observations of other authors. For example, Musa et al. [57], who studied the antimicrobial activity of extracts from various organs of this type of Amaranthus did not find any antibacterial effect, not only against staphylococcus strains, but also against other test bacteria. The results of our observation do not coincide with the data of other authors and, according to the spectrum of action of the extract from A. tricolor on the reference and hospital strains of microorganisms used in the work. In our study, this extract showed a distinct effect on strains of $S$. aureus and $P$. aeruginosa, not having activity against strains of $E$. coli. At the same time, several authors reported a pronounced degree of bactericidal activity of $A$. tricolor against these bacteria [58-60].

Usma or black henna (I. tinctoria) is used not only in cosmetics but is also widely used in traditional medicine. Based on this fact, we studied the antibacterial properties of the extract obtained from the leaves of this plant. Our observations show that the extract from $I$. tinctoria has negligible antibacterial activity relative to the reference and hospital strains of $S$. aureus, $P$. aeruginosa and did not affect $E$. coli and $K$. pneumoniae strains, which corroborates the results of a study by some authors $[61,62]$ but is not consistent with the data of other researchers who demonstrated antimicrobial activity of $I$. tinctoria extracts [63] against S. aureus, E. faecalis, K. pneumoniae, Enterobacter aerogenes, and Salmonella paratyphi [64].

In folk medicine in different countries, different parts of the pomegranate plant ( $P$. granatum) has been used since biblical times $[65,66]$. It is reported that extracts extracted from the leaves, peel, fruits and root of this plant have antimicrobial activity and are effective against many diseases of an infectious nature [67-71]. It was recently once more confirmed that ethanol extracts from aril, albedo and peel have suppressed growth of $E$. coli, S. aureus, P. aeruginosa and Bacillus subtilus [72]. The leaves hydro-methanolic extract has antimicrobial activity against Listeria monocytogenes, Clostridium perfringens, S. aureus, B. cereus, Enterococcus faecalis, Shigella flexneri, Vibrio parahaemolyticus, Proteus vulgaris [73]. According to Nozohour et al. [74] seeds and peel showed inhibitory effects on the growth and proliferation of clinical isolates of $P$. aeruginosa and $S$. aureus. This is similar to our results even though in our case, the activity was much lower.

Henna (L. inermis) leaves have been extensively used for centuries in India and many other Asian and African countries for cosmetic dye and in treating skin problems, headache, jaundice, amebiasis and enlargement of the spleen [75]. However, the opinions of the authors [63, 76-78] with regard to its antimicrobial activity differ and do not in all cases agree with the results of our study. There are reports of a high inhibitory ability of its extract against the reference and clinical strains of $P$. aeruginosa, $K$. pneumoniae, $E$. coli and many other etiological agents of purulent inflammatory diseases and pathogens of intestinal infections. For example, Kouadri reported that ethanol extract had moderate anti-inflammatory effect on $S$. aureus and $K$. pneumoniae, while the methanol extract of $L$. inermis exhibited a higher degree of antimicrobial activity against $S$. aureus, P. aeruginosa, E. coli, K. pneumoniae, E. faecalis, Enterobacter cloacae [79]. In our study, the extract from the leaves of this plant only partially inhibited the growth of only reference strain of $S$. aureus and $P$. aeruginosa.

The beneficial properties of representatives of the Allium genus are well known $[80,81]$. In folk medicine in many countries, their use is especially common as antiviral and immunomodulating agents due to the high content of aromatic oils and volatile products. Natural and climatic factors can also influence their composition. Particular attention is paid to the endemic species of Allium. Onion of Suvorov (A. suworowii), also known as Anzur, has long been used in Central Asia for canning. It is characterized by a specific taste and aroma. In the course of the study, A. suworowii antibacterial properties were studied, where they showed an inhibitory effect on $S$. aureus in an average degree against standard and museum strains, while in case of $P$. aeruginosa, it showed activity only against reference strains and did not show an inhibitory effect against hospital strain and also did not demonstrate antibacterial activity against strains of $E$. coli and $K$. pneumoniae.

The results of our study showed that the extract from S. media leave extract has minimal antimicrobial activity against $S$. aureus, $P$. aeruginosa and $E$. coli reference strains, which does not coincide with the data of Melnyk et al. [82], who report its high activity against both $S$. aureus and $P$. aeruginosa. Yildirim et al. [83], on the other hand showed that this species extract does not inhibit the growth of strains of $S$. aureus, $P$. aeruginosa, E. coli and was active against K. pneumoniae.

The results of our research are not in accord with the data of other authors on the antibacterial activity of the extract from $Z$. mays. According to Saleh et al. [84] and Iwalokun et al. [85], extracts from this plant species give a high inhibition effect against gram-positive bacteria, including $S$. aureus and many gram-negative bacteria - P. aeruginosa, K. pneumoniae, E. coli with a suppression zone. In our case, this extract showed minimal activity against hospital and reference strains of $E$. coli.

The study of the spectrum of antibacterial activity of the examined plants showed that the extract from $C$. annuum also has a minimal suppressive activity against reference strains of $S$. aureus and $P$. aeruginosa. Here, there is some agreement between the results of our research and the data obtained by Koffi-Nevry et al. [86] and Nurjanah et al. [87]. 


\section{CONCLUSIONS}

The results of current study showed that among the 18 plant species growing in the central part of the Republic of Tajikistan, extracts of 16 species have antimicrobial effects of varying strengths. The studied plant extracts differ among themselves, both in the spectrum and degree of antibacterial activity against the reference and hospital strains used in the assays. Extracts from the leaves of $A$. absinthium and $M$. nigra have a broad antimicrobial effect and differ only in degree of activity. The extracts of $A$. tricolor and $A$. tomentosum, I. tinctoria, $P$. granatum were characterized by a narrow spectrum of action; $M$. arvensis and $A$. suworowii - with approximately the same degree of inhibitory ability. In our opinion, the difference between the results of our study and published data may be explained by the effects of intra specific variability in the formation of biologically active compounds, seasonality, methods of extraction of biologically active substances and methods for testing biological activity.

\section{REFERENCES}

1. Chain E, Florey HW, Gardner AD, Heatley NG, Jennings MA, Orr-Ewing J, et al. Penicillin as a chemotherapeutic agent. The Lancet. 1940; 236(6104):226-8.

2. Quinn R. Rethinking antibiotic research and development: World War II and the penicillin collaborative. American Journal of Public Health. 2013;103(3):426-34.

3. Fleming A. Sir Alexander Fleming - Nobel Lecture.: Nobel Prize.org. Nobel Media $A B$ 2019; 2019 [Available from: https://www.nobelprize.org/prizes/ medicine/1945/fleming/lecture/.

4. Regea G. Review on antibiotics resistance and its economic impacts. J Pharmacol Clin Res. 2018;5:555675

5. Marston HD, Dixon DM, Knisely JM, Palmore TN, Fauci AS. Antimicrobial resistance. JAMA. 2016;316(11):1193-204

6. Blunston MA, Yonovitz A, Woodahl EL, Smolensky MH. Gentamicin-induced ototoxicity and nephrotoxicity vary with circadian time of treatment and entail separate mechanisms. Chronobiology International. 2015;32(9):1223-32.

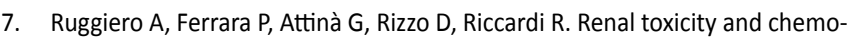
therapy in children with cancer. British Journal of Clinical Pharmacology. 2017;83(12):2605-14

8. Mulat M, Pandita A, Khan F. Medicinal plant compounds for combating the multi-drug resistant pathogenic bacteria: A Review. Current Pharmaceutical Biotechnology. 2019;20(3):183-96.

9. Hossan MS, Jindal H, Maisha S, Samudi Raju C, Devi Sekaran S, Nissapatorn V, et al. Antibacterial effects of 18 medicinal plants used by the Khyang tribe in Bangladesh. Pharmaceutical Biology. 2018;56(1):201-8.

10. Raskin I, Ribnicky DM, Komarnytsky S, llic N, Poulev A, Borisjuk N, et al. Plants and human health in the twenty-first century. Trends in Biotechnology. 2002;20(12):522-31.

11. Dushenkov V, Graf BL, Lila MA. Botanical therapeutics in the modern world. In: Sidelnikov NI. (ed.) Biological characteristics of medicinal and aromatic plants and role of these plants in medicine. Moscow, RF: FGBNU, VILAR; 2016. p. 50-4.

12. Adebooye OC, Alashi AM, Aluko RE. A brief review on emerging trends in global polyphenol research. Journal of Food Biochemistry. 2018;42(4):e12519.

13. Gautam VK, Datta M, Baldi A. Effect of geographical and seasonal variations on phenolic contents and antioxidant activity of aerial parts of Urtica diocia L. Current Traditional Medicine. 2019;5(2):159-67.

14. Raudone L, Motiekaityte V, Vainoriene R, Zymone K, Marksa M, Janulis V. Phytochemical profiles of alpine plant Horminum Pyrenaicum L. during phenological growth stages. Chemistry \& Biodiversity. 2018;15(10):e1800190.

15. Gouvea DR, Gobbo-Neto L, Lopes NP. The influence of biotic and abiotic factors on the production of secondary metabolites in medicinal plants. Plant Bioactives and Drug Discovery: Principles, Practice, and Perspectives. 2012;17:419.

16. Khodzhimatov M. Dikorastushchie lekarstvennye rasteniya Tadzhikistana [Wild medicinal plants of Tajikistan]. Dushanbe, RT: Soviet Encyclopedia; 1989. 364 p.

17. Nuraliev YuN. Lekarstvennye rasteniya [Medicinal plants]. Dushanbe, RT: Publishing Outfit Education; 1988. 288 p.
18. Skubel SA, Dushenkov V, Graf BL, Niu Q, Poulev A, Kalariya HM, et al. Rapid, field-deployable method for collecting and preserving plant metabolome for biochemical and functional characterization. PloS One. 2018;13(9):e0203569.

19. CLSI. Methods for dilution antimicrobial susceptibility tests for bacteria that grow aerobically; approved standards. Tenth edition. CLSI, 940 West Valley Road, Suite 1400, Wayne, Pennsylvania 19087-1898 USA 2015.

20. Kellogg J, Joseph G, Andrae-Marobela K, Sosome A, Flint C, Komarnytsky S, et al. Screens-to-Nature: Opening Doors to Traditional Knowledge and Handson Science Education1. Urbana. 2010;51:61801.

21. Joseph G, Faran M, Raskin I, Lila M, Fridlender B. Medicinal plants of Israel: a model approach to enable an efficient, extensive, and comprehensive field survey. J Biodivers Biopros Dev. 2014;1:134. Available from: https://doi. org/10.4172/2376-0214.1000134.

22. Rahmoun N M, Ziane H, Boucherit-Otmani Z. Antibacterial and antifungal screening of four medicinal plants. Journal of Coastal Life Medicine. 2014;2(12):975-9.

23. Asgeirsson $\mathrm{H}$, Thalme $A$, Weiland $O$. Staphylococcus aureus bacteraemia and endocarditis - epidemiology and outcome: a review. Infectious Diseases. 2018;50(3):175-92

24. Pachori P, Gothalwal R, Gandhi P. Emergence of antibiotic resistance Pseudomonas aeruginosa in intensive care unit; a critical review. Genes \& Diseases. 2019;6(2):109.

25. Dong F, Zhang Y, Yao K, Lu J, Guo L, Lyu S, et al. Epidemiology of carbapenem-resistant Klebsiella pneumoniae bloodstream infections in a Chinese Children's Hospital: predominance of New Delhi metallo- $\beta$-lactamase-1. Microbial Drug Resistance. 2018;24(2):154-60.

26. Pulipati S, Babu PS, Narasu ML. Quantitative determination of tannin content and evaluation of antibacterial activity of Amaranthus tricolor (L). Int J Bio Pharm Res. 2014;5:623-6.

27. Cherian P, Sheela D. Antimicrobial activity of Amaranth Alkaloid against pathogenic microbes. International Journal of Herbal Medicine. 2016;4:70-2

28. Moslemi HR, Hoseinzadeh $\mathrm{H}$, Badouei MA, Kafshdouzan K, Fard RMN. Antimicrobial activity of Artemisia absinthium against surgical wounds infected by Staphylococcus aureus in a rat model. Indian Journal of Microbiology. 2012;52(4):601-4.

29. Ahamad J, Mir SR, Amin S. A pharmacognostic review on Artemisia absinthium. International Research Journal of Pharmacy. 2019(10):25-31.

30. Budiman A, Aulifa DL, Kusuma ASW, Sulastri A. Antibacterial and antioxidan activity of black mulberry (Morus nigra L.) extract for acne treatment. Pharmacognosy Journal. 2017;9(5):611-4.

31. Aulifa DL, Fitriansyah SN, Ardiansyah SA, Wibowo DP, Julata YA, Christy DS Phytochemical screening, antibacterial activity, and mode of action on Morus nigra. Pharmacognosy Journal. 2018;10(1):167-71.

32. Khalid N, Fawad SA, Ahmed I. Antimicrobial activity, phytochemical profile and trace minerals of black mulberry (Morus nigra L.) fresh juice. Pak J Bot 2011;43(6):91-6.

33. Egamberdieva D, Mamedov N, Ovidi E, Tiezzi A, Craker L. Phytochemical and pharmacological properties of medicinal plants from Uzbekistan: A review. Journal of Medicinally Active Plants. 2017;5(2):59-75. 
34. Ozturk S, Ercisli S. Antibacterial activity of aqueous and methanol extracts of Althaea officinalis and Althaea cannabina from Turkey. Pharmaceutical Biology. 2007;45(3):235-40.

35. Negi P, Chauhan A, Sadia G, Rohinishree Y, Ramteke R. Antioxidant and antibacterial activities of various seabuckthorn (Hippophae rhamnoides L.) seed extracts. Food Chemistry. 2005;92(1):119-24.

36. Wani TA, Wani S, Ahmad M, Ahmad M, Gani A, Masoodi F. Bioactive profile, health benefits and safety evaluation of sea buckthorn (Hippophae rhamnoides L.): A review. Cogent Food \& Agriculture. 2016;2(1):1128519.

37. Suryakumar G, Gupta A. Medicinal and therapeutic potential of Sea buckthorn (Hippophae rhamnoides L.). Journal of Ethnopharmacology. 2011;138(2):268-78.

38. Upadhyay NK, Kumar MY, Gupta A. Antioxidant, cytoprotective and antibacterial effects of Sea buckthorn (Hippophae rhamnoides L.) leaves. Food and Chemical Toxicology. 2010;48(12):3443-8.

39. Radenkovs V, Püssa T, Juhnevica-Radenkova K, Anton D, Seglina D. Phytochemical characterization and antimicrobial evaluation of young leaf/shoot and press cake extracts from Hippophae rhamnoides L. Food Bioscience. 2018;24:56-66.

40. Michel T, Destandau E, Le Floch G, Lucchesi ME, Elfakir C. Antimicrobial, antioxidant and phytochemical investigations of sea buckthorn (Hippophaë rhamnoides L.) leaf, stem, root and seed. Food Chemistry. 2012;131(3):754-60.

41. Karomatov ID. Lopiu, repeynik - perspektivnoe rastitel'noe lekarstvennoe sredstvo [Burdock - a promising herbal remedy]. Biologiya $i$ integrativnaya meditsina. 2017;5:64-182.

42. Sõukand R, Kalle R. Changes in the use of wild food plants in Estonia: $18^{\text {th }}-21^{\text {st }}$ century. Springer; 2016. $172 \mathrm{p}$.

43. Wang D, Bădărau AS, Swamy MK, Shaw S, Maggi F, Da Silva LE, et al. Arctium species secondary metabolites chemodiversity and bioactivities. Frontiers in Plant Science. 2019;10(Article 834):1-27.

44. Tousch D, Bidel LP, Cazals G, Ferrare K, Leroy J, Faucanié M, et al. Chemical analysis and antihyperglycemic activity of an original extract from burdock root (Arctium lappa). Journal of Agricultural and Food Chemistry. 2014;62(31):7738-45.

45. Sychev IA, Kokina DG. Study of composition, physical and chemical properties and biological activity of polysaccharide complex of Arctium lappa leaves. IP Pavlov Russian Medical Biological Herald. 2017;25(1):42-8.

46. Lou Z, Li C, Kou X, Yu F, Wang H, Smith GM, et al. Antibacterial, antibiofilm effect of Burdock (Arctium lappa L.) leaf fraction and its efficiency in meat preservation. Journal of Food Protection. 2016;79(8):1404-9.

47. Chen J, Li W, Jin E, He Q, Yan W, Yang H, et al. The antiviral activity of arctigenin in traditional Chinese medicine on porcine circovirus type 2. Research in M Veterinary Science. 2016;106:159-64.

48. Zhao J, Evangelopoulos D, Bhakta S, Gray Al, Seidel V. Antitubercular activity of Arctium lappa and Tussilago farfara extracts and constituents. Journal of Ethnopharmacology. 2014;155(1):796-800.

49. Sõukand R, Hrynevich Y, Vasilyeva I, Prakofjewa J, Vnukovich Y, Paciupa J, et al. Multi-functionality of the few: current and past uses of wild plants for food and healing in Liubań region, Belarus. Journal of Ethnobiology and Ethnomedicine. 2017;13(10):1-42.

50. Pirvu L, Nicorescu I, Hlevca C, Albu B, Nicorescu V. Burdock (Arctium lappa) leaf extracts the in vitro antimicrobial efficacy of common antibiotics on gram-positive and gram-negative bacteria. Open Chemistry. 2017;15(1):92-102.

51. Brasileiro BG, Pizziolo VR, Raslan DS, Jamal CM, Silveira D. Antimicrobial and cytotoxic activities screening of some Brazilian medicinal plants used in Governador Valadares district. Revista Brasileira de Ciências Farmacêuticas. 2006;42(2):195-202.

52. Salehi B, Stojanović-Radić Z, Matejić J, Sharopov F, Antolak H, Kręgiel D, et al. Plants of genus Mentha: from farm to food factory. Plants. 2018;7(3):70.

53. Anwar F, Abbas A, Mehmood T, Gilani AH, Rehman Nu. Mentha: A genus rich in vital nutra-pharmaceuticals - A review. Phytotherapy Research. 2019;33:2548-70.

54. Sugandhi BRM, Bai GM. Antimicrobial activity of Mentha arvensis L. (Lamiaceae). Journal of Advanced Laboratory Research in Biology. 2011;2(1):8-11.

55. Johnson M, Wesely E, Kavitha M, Uma V. Antibacterial activity of leaves and inter-nodal callus extracts of Mentha arvensis L. Asian Pacific Journal of Tropical Medicine. 2011;4(3):196-200.

56. Hamed FM, Shalaal S, Hlail AT, Hassan BA. Phytochemical and antimicrobial study of acetone extracts of menthe and olive leaves. The Journal of Research on the Lepidoptera. 2019;50(2):51-6.
57. Musa F, Alatery A, Aburawi S, Alzatreny A, Hamrouni A, Auzi A. Phytochemical, antioxidant, antibacterial and anti-inflammatory investigation of the methanolic extract of Amaranthus tricolor Seed. Tripolitana Medical Journal. 2012;1(2):94-9.

58. Fatimah I, Aftrid ZHVI. Characteristics and antibacterial activity of green synthesized silver nanoparticles using red spinach (Amaranthus Tricolor L.) leaf extract. Green Chemistry Letters and Reviews. 2019;12(1):25-30.

59. Ullah MO, Haque M, Urmi KF, Zulfiker AHM, Anita ES, Begum M, et al. Anti-bacterial activity and brine shrimp lethality bioassay of methanolic extracts of fourteen different edible vegetables from Bangladesh. Asian Pacific Journal of Tropical Biomedicine. 2013;3(1):1-7.

60. Srivastava R. An updated review on phyto-pharmacological and pharmacognostical profile of Amaranthus tricolor: a herb of nutraceutical potentials. The Pharma Innovation. 2017;6(6, Part B):124-9.

61. Saadabi MA. Evaluation of Lawsonia inermis Linn. (Sudanese henna) leaf extracts as an antimicrobial agent. Research Journal of Biological Sciences. 2007;2(4):419-23.

62. Renukadevi K, Sultana SS. Determination of antibacterial, antioxidant and cytotoxicity effect of Indigofera tinctoria on lung cancer cell line $\mathrm{NCl}$-h69. Int J Pharmacol. 2011;7:356-62.

63. Rimawi MA, Masri MA, Husein N, Al-Hinnawi ANT, Masimi OA, Sabrah L. Natural antimicrobial activity of Lawsonia inermis and Indigo tinctoria against clinically isolated microorganisms. Int J Pharm Pharm Sci. 2017;10(1):191-4.

64. Swaminathan C. Phytochemical analysis and antibacterial and antioxidant properties of Indigofera tinctoria L. Asian J Pharm and Clinical Res. 2018;11(6):136-8.

65. Evans WC. Trease and Evans' pharmacognosy, $16^{\text {th }}$ Edition. Elsevier Health Sciences; 2009.

66. Singh B, Singh JP, Kaur A, Singh N. Antimicrobial potential of pomegranate peel: a review. International Journal of Food Science \& Technology. 2019;54(4):959-65.

67. Arul J. Punica granatum: a review on phytochemicals, antioxidant and antimicrobial. Journal of Academia and Industrial Research. 2017;5(9):132-8.

68. Dahham SS, Ali MN, Tabassum H, Khan M. Studies on antibacterial and antifungal activity of pomegranate (Punica granatum L.). Am Eurasian J Agric Environ Sci. 2010;9(3):273-81.

69. Hegde Chaitra R, Madhuri M, Swaroop TN, Arijit D, Sourav B, Rohit K. Evaluation of antimicrobial properties, phytochemical contents and antioxidant capacities of leaf extracts of Punica granatum L. ISCA J of Biological Sciences. 2012;1(2):32-7.

70. Nitave SA, Patil VA. Study of antibacterial and antifungal activity of Punica granatum peel and its phytochemical screening. World Journal of Pharmaceutical Research. 2014;3(10):505-12.

71. Pai V, Chanu TR, Chakraborty R, Raju B, Lobo R, Ballal M. Evaluation of the antimicrobial activity of Punica granatum peel against the enteric pathogens: an in vitro study. Asian Journal of Plant Science and Research. 2011;1(2):57-62.

72. Danial EN, Basudan N. Comparative study as antioxidant, antimicrobial activities and total phenolic content between various parts of pomegranate. RJLBPCS. 2019;5(2):6474-684.

73. Youssef $\mathrm{H}, \mathrm{El}-\mathrm{Mahmoudy}$ AM. Evaluation of the antimicrobial potential of Punica Granatum leaves hydro-methanolic extract against selected pathogens. American Journal of Current Microbiology. 2019;7(1):23-33.

74. Nozohour Y, Golmohammadi R, Mirnejad R, Fartashvand M. Antibacterial activity of pomegranate (Punica granatum L.) seed and peel alcoholic extracts on Staphylococcus aureus and Pseudomonas aeruginosa isolated from health centers. Journal of Applied Biotechnology Reports. 2018;5(1):32-6.

75. Al-Snafi AE. A review on Lawsonia inermis: a potential medicinal plant. Int J Curr Pharm Res. 2019;11(5):1-13.

76. El-Hag A, Al-Jabri A, Habbal O. Antimicrobial properties of Lawsonia inermis (henna): a review. Australian Journal of Medical Herbalism. 2007;19(3):114.

77. Habbal O, Hasson S, El-Hag A, Al-Mahrooqi Z, Al-Hashmi N, Al-Bimani Z, et al. Antibacterial activity of Lawsonia inermis Linn (Henna) against Pseudomonas aeruginosa. Asian Pacific Journal of Tropical Biomedicine. 2011;1(3):173-6.

78. Al-Daamy AAHK, Hassan AA, Mahmood A. Study of antibacterial activity of Lawsonia inermis leaf extract. Journal of Contemporary Medical Sciences. 2016;2(7):103-6

79. Kouadri F. In vitro antibacterial and antifungal activities of the Saudi Lawsonia inermis extracts against some nosocomial infection pathogens. Journal of Pure and Applied Microbiology. 2018;12(1):281-6. 
80. Ajami M, Vazirijavid R. Garlic (Allium sativum L.). Nonvitamin and nonmineral nutritional supplements. Elsevier; 2019. p. 227-34.

81. Teshika JD, Zakariyyah AM, Zaynab T, Zengin G, Rengasamy KR, Pandian SK, et al. Traditional and modern uses of onion bulb (Allium cepa L.): A Systematic Review. Critical Reviews in Food Science and Nutrition. 2019;59(sup1):S39-S70.

82. Melnyk MV, Vodoslavskyi VM, Stasiv TG, Zarichanska OV. The study of microbiological activity of medicinal plants of flora of Prycarpathia. International Journal of Green Pharmacy. 2018;12(03):158-61.

83. Yildirim AB, Karakas FP, Turker AU. In vitro antibacterial and antitumor activities of some medicinal plant extracts, growing in Turkey. Asian Pacific Journal of Tropical Medicine. 2013;6(8):616-24

84. Saleh RH, Hindi NKK, Ali MRA. Antibacterial activity of aquatic Zea Mays L. Hairs extract against different bacteria in Babylon province: an in vitro study. Journal of Global Pharma Technology. 2017;8(9):121-9.
85. Iwalokun B, Olukosi Y, Adejoro A, Olaye J, Fashade O. Comparative biochemical and molecular evaluation of swarming of Proteus and effects of anti-swarm agents. African Journal of Biotechnology. 2004;3(1):99-104.

86. Koffi-Nevry R, Kouassi KC, Nanga ZY, Koussémon M, Loukou GY. Antibacterial activity of two bell pepper extracts: Capsicum annuum L. and Capsicum frutescens. International Journal of Food Properties. 2012;15(5):961-71.

87. Nurjanah S, Sudaryanto Z, Widyasanti A, Pratiwi H (eds.) Antibacterial activity of Capsicum annuum L. oleoresin. XXIX International Horticultural Congress on Horticulture: Sustaining Lives, Livelihoods and Landscapes (IHC2014): V World 1125; 2014.

\section{(7) AUthor INFORMATION}

Satorov Saidbeg, Doctor of Medical Sciences, Professor, Head of the Department of Microbiology, Immunology and Virology, Avicenna Tajik State Medical University

SCOPUS: 10419425154

Researcher ID: S-9073-2016

ORCID ID: 0000-0003-1101-1840

Author ID: 78634

SPIN: 2523-8682

E-mail: sattorion@mail.ru

Mirzoeva Fazila, Assistant, Department of Microbiology, Immunology and Virology, Avicenna Tajik State Medical University

ORCID ID: 0000-0003-0187-0334

E-mail: fazila.mirzoeva88@mail.ru

Satorov Shukhrat, Intern of the Department of Plant Biology, School of Environmental and Biological Sciences, Rutgers University

SCOPUS: 1742026179

ORCID ID: 0000-0003- 3072-1135

E-mail: sufion@mail.ru

Vakhidova Manizha, Intern of the Department of Plant Biology, School of Environmental and Biological Sciences, Rutgers University

ORCID ID: 0000-0002-3366-1580

SPIN: 9366-9702

E-mail:sufion@mail.ru

Dushenkov Vyacheslav, PhD, Associate Professor at the Department of Natural Sciences, Hostos Community College, City University of New York SCOPUS: 6507356097

Researcher ID: AAE-8520-2019

ORCID ID: 0000-0001- 5176-7461

Author ID: 638952

SPIN: 50533-0988

E-mail: dushenkov@sebs.rutgers.edu

Information about the source of support in the form of grants, equipment, and drugs

The authors did not receive financial support from manufacturers of medicines and medical equipment

Conflicts of interest: The authors have no conflicts of interest

\section{СВЕДЕНИЯ ОБ АВТОРАХ}

Саторов Саидбег, доктор медицинских наук, профессор кафедры микробиологии, иммунологии и вирусологии, Таджикский государственный медицинский университет им. Абуали ибни Сино

SCOPUS: 10419425154

Researcher ID: S-9073-2016

ORCID ID: 0000-0003-1101-1840

Author ID: 78634

SPIN код: 2523-8682

E-mail: sattorion@mail.ru

Мирзоева Фазила, ассистент кафедры микробиологии, иммунологии и вирусологии, Таджикский государственный медицинский университет им. Абуали ибни Сино

ORCID ID: 0000-0003-0187-0334

E-mail: fazila.mirzoeva88@mail.ru

Саторов Шухрат, стажёр кафедры биологии растений, Школа экологических и биологических наук, Ратгерский Университет

SCOPUS: 1742026179

ORCID ID: 0000-0003-3072-1135

E-mail: sufion@mail.ru

Вахидова Манижа, стажёр кафедры биологии растений, Школа экологических и биологических наук, Ратгерский Университет

ORCID ID: 0000-0002-3366-1580

SPIN код: 9366-9702

E-mail: sufion@mail.ru

Душенков Вячеслав, доктор медицинских наук, профессор кафедры естественных наук, Хостоский общественный колледж, Городской Университет Нью-Йорка

SCOPUS: 6507356097

Researcher ID: AAE-8520-2019

ORCID ID: 0000-0001- 5176-7461

Author ID: 638952

SPIN код: 50533-0988

E-mail: dushenkov@sebs.rutgers.edu

Информация об источнике поддержки в виде грантов, оборудования, лекарственных препаратов

Финансовой поддержки со стороны компаний-производителей лекарственных препаратов и медицинского оборудования авторы не получали

Конфликт интересов: отсутствует 


\section{ADDRESS FOR CORRESPONDENCE:}

\section{Satorov Saidbeg}

Doctor of Medical Sciences, Professor, Head of the Department of Microbiology, Immunology and Virology, Avicenna Tajik State Medical University

734003, Republic of Tajikistan, Dushanbe, Rudaki Ave., 139

Tel.: +992 (987) 842424

E-mail: sattorion@mail.ru

AUTHOR CONTRIBUTIONS
Conception and design: SS, DV
Data collection: MF, SSh, VM
Statistical analysis: SSh, VM
Analysis and interpretation: SS, MF, VM
Writing the article: MF, DV
Critical revision of the article: SS, DV
Overall responsibility: SS

$\begin{array}{ll}\text { Submitted } & 27.09 .2019 \\ \text { Accepted } & 25.12 .2019\end{array}$

\section{АДРЕС ДЛЯ КОРРЕСПОНДЕНЦИИ}

\section{Саторов Саидбег}

доктор медицинских наук, профессор кафедры микробиологии, иммунологии и вирусологии, Таджикский государственный медицинский университет им. Абуали ибни Сино

734003, Республика Таджикистан, г. Душанбе, пр. Рудаки, 139 Тел.: +992 (987) 842424

E-mail: sattorion@mail.ru

\section{ВКЛАД АВТОРОВ}

Разработка концепции и дизайна исследования: СС, ДВ Сбор материала: МФ, СШ, ВМ

Статистическая обработка данных: СШ, ВМ

Анализ полученных данных: СС, МФ, ВМ

Подготовка текста: МФ, ДВ

Редактирование: СС, ДВ

Общая ответственность: СС

$\begin{array}{ll}\text { Поступила } & 27.09 .2019 \\ \text { Принята в печать } & 25.12 .2019\end{array}$

